\title{
Coalified bitumens from the Kłodawa Salt Structure (central Poland) as evidence of migration of hydrothermal fluids in Zechstein (Upper Permian) deposits
}

\author{
Marian WAGNER ${ }^{1}$ and Stanisław BURLIGA ${ }^{2, *}$ \\ 1 AGH University of Science and Technology, Al. A. Mickiewicza 30, 30-962 Kraków, Poland \\ 2 University of Wrocław, Institute of Geological Sciences, M. Borna 9, 50-204 Wrocław, Poland
}

Wagner, M., Burliga, S., 2014. Coalified bitumens from the Kłodawa Salt Structure (central Poland) as evidence of migration of hydrothermal fluids in Zechstein (Upper Permian) deposits. Geological Quarterly, 58 (3): 555-564, doi: 10.7306/gq.1127

\begin{abstract}
The paper presents the results of petrographic and geochemical studies of coaly matter occurring in Stinking Shale and Main Dolomite (PZ2, Upper Permian) deposits in the Kłodawa Salt Structure in central Poland. The coaly matter is both dispersed in the PZ2 shales and carbonates and concentrated in veins which crosscut these deposits and, depending on the location, depicts contrasting maceral composition and the rank of coal. The veins are built of colotellinite and micrinite, showing a mean random reflectance of coal in the range of $1.38-1.40 \%$, whereas the dispersed organic matter is composed mostly of semifusinite and fusinite with minor vitrinite, showing a mean random reflectance of $0.82 \%$. It is interpreted that the heterogeneous composition and rank of coal result from migration of hot fluids within a fracture system developed in the PZ2 shale and carbonate beds. The influx of hot fluids into the organic matter-rich beds led to the generation of bitumen which catagenetically altered along the hot fluid conduits. The coalification of bitumens took place at an early stage of tectonic deformation of the Zechstein salt series, initiated by regional extension and normal displacement on a basement fault, most probably in the Late Permian-Early Triassic.
\end{abstract}

Key words: collotelinite, micrinite, vitrinization of bitumens, Kłodawa Salt Structure, Main Dolomite, Stinking Shale.

\section{INTRODUCTION}

Zechstein (Upper Permian) evaporite sequences in Poland display a contrasting content of organic matter (OM). The variability in respect to OM content results primarily from the cyclicity in marine sedimentation, i.e. from the repetitive occurrence of transgressive-regressive cycle deposits in the Zechstein Basin. The relatively OM-rich deposits typically accumulate at the beginning of a transgressive cycle and in the Zechstein evaporitic sequences they mostly correlate with siliceous and calcareous shales and carbonates deposited at the base of the two oldest evaporitic cycles (Peryt et al., 2010). The OM-poor beds dominantly consist of rock salt and potash, both regarded as regressive deposits in a cycle. The content of the dispersed OM in rocks, measured as the total organic carbon (TOC) content, enables to compare distinct lithological varieties. Although the present TOC content is generally low in the Zechstein carbonates (Ca1, Zechstein Limestone, and Ca2, Main Dolomite), ranging between 0.01 and 1.0 wt.\% (Kotarba et al., 2006; Kotarba and Wagner, 2007; Słowakiewicz and Mikołajewski, 2011), a significant increase of TOC content is locally observed, which may be as high as 6.25 wt.\% (Kotarba et al., 2000). The variation of the

\footnotetext{
*Corresponding author: stanislaw.burliga@ing.uni.wroc.pl
}

Received: May 29, 2013; accepted: October 6, 2013; first published online: October 24, 2013
TOC content was also evidenced by Kotarba et al. (2006) in shales of the first Zechstein cycle (Kupferschiefer, T1), which ranges from 0.01 to $15.5 \mathrm{wt} . \%$, being $3.1 \mathrm{wt} . \%$ on average. Similarly, also thermal maturation estimated according to the vitrinite reflectance scale varies in these rocks. The reflectance values vary in a range of $<0.7 \% R_{\circ}$ up to $3.2 \% R_{\circ}$ throughout the Zechstein Basin and this is primarily dependent on the depth of burial and tectonics (Karnkowski, 2007; Słowakiewicz and Mikołajewski, 2011). However, remarkable differences in vitrinite reflectance are recorded over small areas at similar depths of burial (compare data presented by Kotarba et al., 2006; Kotarba and Wagner, 2007; Słowakiewicz and Mikołajewski, 2011). Because there is no detailed information about the sampled material and the local variability in the TOC and reflectance values are not discussed in these papers, the variation remains unclear. Whereas local increase in the TOC content may result from primary distribution as well as from diagenetic or tectonic concentration, e.g. due to solution-precipitation processes (Hofmann and Leythaeuser, 1995; Leythaeuser et al., 1995), the variability in reflectance is more enigmatic.

Recent investigations carried out in the Kłodawa Salt Structure (KSS) in central Poland demonstrate the occurrence of OM-enriched veins within the Stinking Shale (T2) and Main Dolomite (Ca2) rocks (Czechowski et al., 2011). An intriguing component of these OM-rich rocks is a coaly matter that, based on preliminary studies, was referred to as solid bitumens (Czechowski et al., 2011). These are black, shining chips resembling coal, dispersed among epigenetic minerals filling the veins. The physical features of the coaly matter indicate a high rank of 
coalification of the OM, provoking questions of its origin within the salt structure. This paper primarily focuses on detailed analysis of this coaly matter, i.e. on its petrography, chemical composition, maturity and origin. We will also discuss the implications arising from the presence of the coaly matter on the geological evolution of the central part of the Polish Zechstein Basin as well as on hydrocarbon generation in the KSS.

\section{GEOLOGICAL SETTING}

The KSS is a salt ridge extending NW-SE in central Poland, developed from Zechstein evaporites deposited in the axial part of the Polish Zechstein Basin (Fig. 1) - a sub-basin in the Southern Permian Basin (Ziegler, 1990). The evolution of the KSS was controlled by basement faults (Burliga, 1996a, b), which is well-evidenced by the salt ridge geometry and asymmetry in the thickness of Mesozoic deposits on the NE and SW flanks of the KSS, imaged on seismic sections (Krzywiec, 2012). The evolution of the salt structure included two major stages: lateral flow of Zechstein evaporites towards the rising salt ridge and their vertical flow during growth of the diapiric structure. The lateral stage initiated at least in the Early Triassic and the upward flow of evaporites in the Middle Triassic at latest (Burliga, 1996a). The salt structure pierced its cover in the Late Triassic and extruded to the surface (Krzywiec, 2004). The post-Triassic evolution of the KSS in the study area cannot be restored in detail because the Polish Zechstein-Mesozoic Basin inverted in the Late Cretaceous-Early Paleogene and erosion

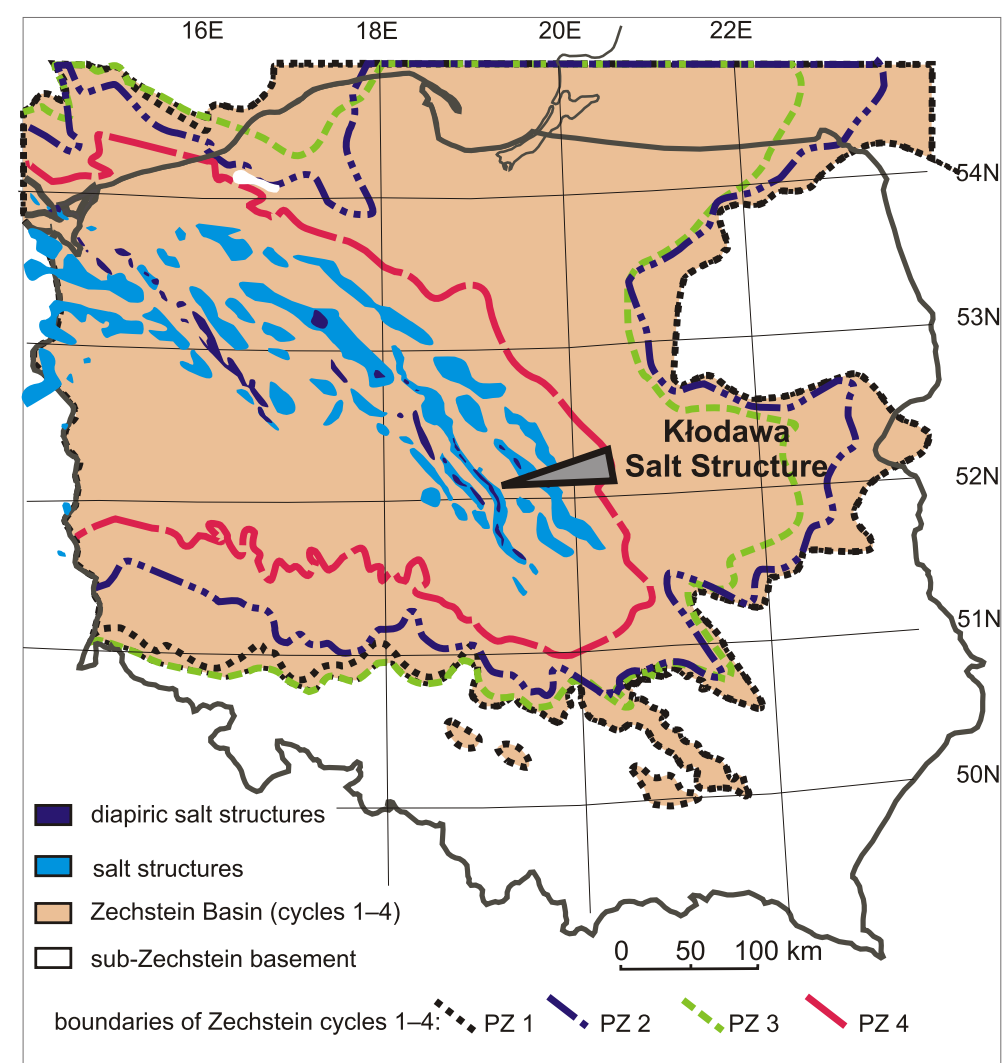

Fig. 1. Location of the Kłodawa Salt Structure in relation to the Polish Zechstein Basin

Limits of Zechstein cycles after Wagner (1998), salt structures after Lockhorst (1998) removed almost all Mesozoic strata overlying the salt structure. Based on the geometry and thickness of Jurassic and Cretaceous strata, noticeable on seismic sections on both flanks of the ridge (Krzywiec, 2004, 2012), it can be concluded that this diapiric structure was reactivated in the time span between the Late Triassic salt extrusion and the inversion of the basin. The KSS is covered at present by a horizontal sequence of Cenozoic deposits. The above evolution implies that the Zechstein deposits constituting the uppermost part of the KSS could never be buried deeper than 2-3 km in their history.

The flow of salt led to complex shearing and folding of the original sedimentary sequence, which resulted in fracturing, boudinage, folding and overall disintegration of more competent beds (shales, carbonates, sulphates). Currently, they occur predominantly as blocks within ductile rock salt and potash. Despite intensive deformation, deposits of all four cycles (PZ1 to PZ4) identified in the Polish Zechstein Basin (Wagner, 1994; Peryt et al., 2010) are evidenced in the KSS (Fig. 2). However, the beds of the PZ1 cycle (Oldest Halite Na1 and Upper Anhydrite A1g) and the basal shale-carbonate-sulphate series of the PZ2 cycle (Stinking Shale T2, Main Dolomite Ca2 and Basal Anhydrite A2, respectively) have been poorly evidenced in the structure. The basal shale-carbonate-sulphate series of the PZ1 cycle (Kupferschiefer T1, Zechstein Limestone Ca1, Lower Anhydrite A1d) has not been evidenced at all (Burliga et al., 2005). The sulphate-shale-carbonate-sulphate complex, separating the $\mathrm{Na} 1$ and the $\mathrm{Na} 2$, is tectonically extremely distorted and, if occurs, only isolated remnants of shale or anhydrite beds ranging from millimetre to a few metres in size are preserved (Burliga et al., 2008). So far, there have been only a few locations documented in the KSS where the $\mathrm{Ca} 2$ deposits are present. The samples for this study were collected from two boudins consisting of almost complete series, entrapped in rock salt of the PZ1 and PZ2 cycles. The sampling locations are referred to as Site 1 and Site 2 (Fig. 2A). In Site 1, the boundaries between anhydrites, shales and carbonates are planar in the sampling area and the sedimentary series appears to be very weakly deformed, although the beds have rotated to vertical arrangement during salt diapirism. The maximum horizontal extent of this boudin is $\sim 200 \mathrm{~m}$ and its vertical extent is $\sim 100 \mathrm{~m}$ (Fig. 2B). The geometry and dimensions of the boudin in Site 2 are not known because the beds are only partly exposed in one gas outburst cavern. The A1g-T2-Ca2-A2 beds are steep to vertical and show variable deformation in this location. The Stink-

Fig. 2. Location of sampling sites in the Kłodawa Salt Structure

A - map showing a lithologic depth slice at $600 \mathrm{~m}$ below the surface; sites 1 and 2 are located 680 and $572 \mathrm{~m}$ below the surface, respectively, in rock salt anticlinoria separated by a synclinorium built of PZ3-PZ4 deposits; $B$ lithological map of level 690 in the area of Site 1, with location of sampling site; the beds are (sub)vertical in the boudin and extend over a distance of $\sim 100 \mathrm{~m}$; the gallery cross-cutting the $A 1 \mathrm{~g}-\mathrm{A} 2$ series (indicated as $\mathrm{X}-\mathrm{Y}$ line) is located $10 \mathrm{~m}$ above the depth slice shown on the map; C - lithostratigraphic column along section $X-Y$ in $B$; cross-section across the KSS and relative location of sampling sites; the sampling sites are located in largescale salt anticlinoria (secondary diapirs) separated by a synclinorium built of PZ3-PZ4 deposits; maps and sections after Burliga et al. (2005, modified) 

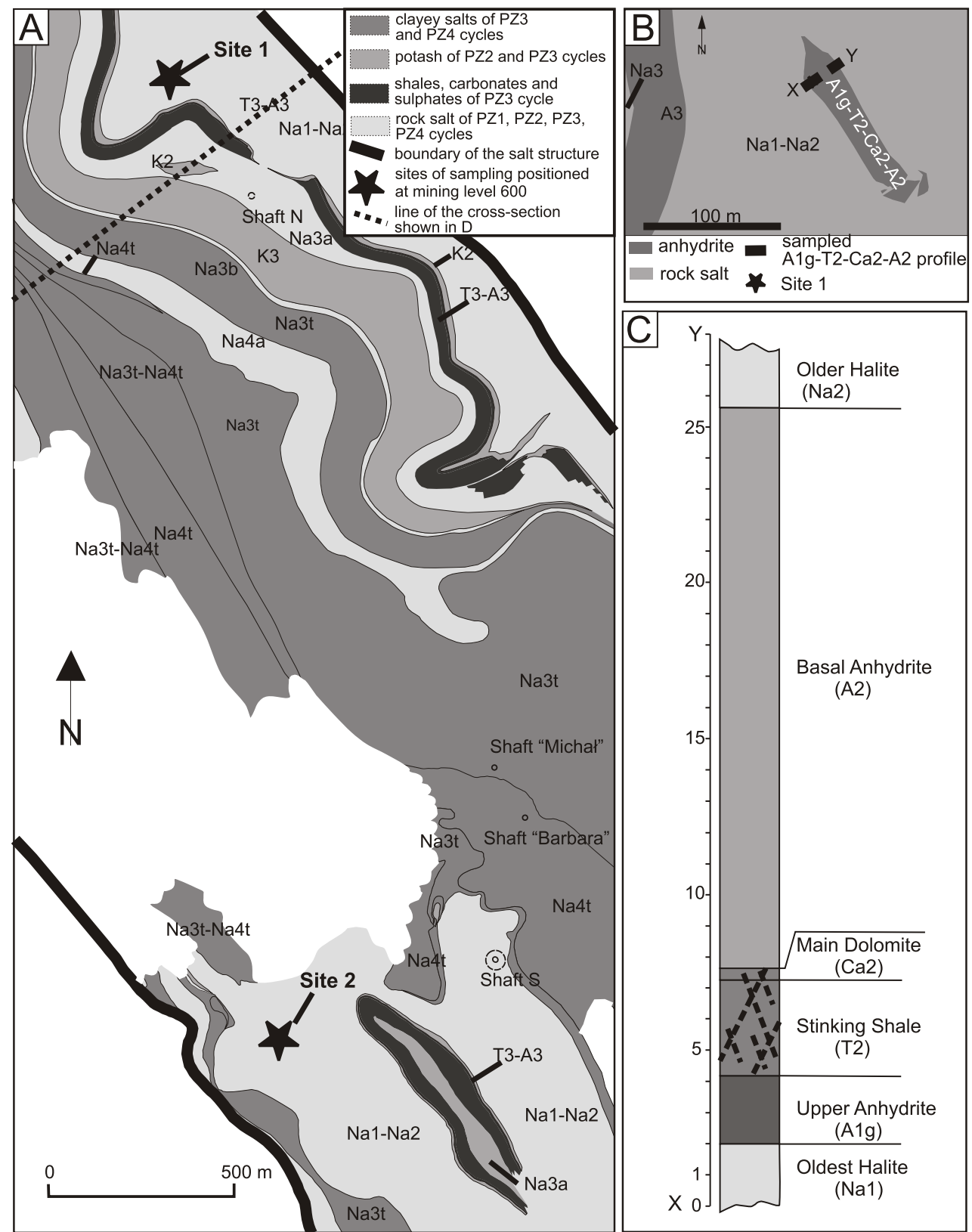

$$
\text { rock salt } \nsucc \text { Site } 1
$$
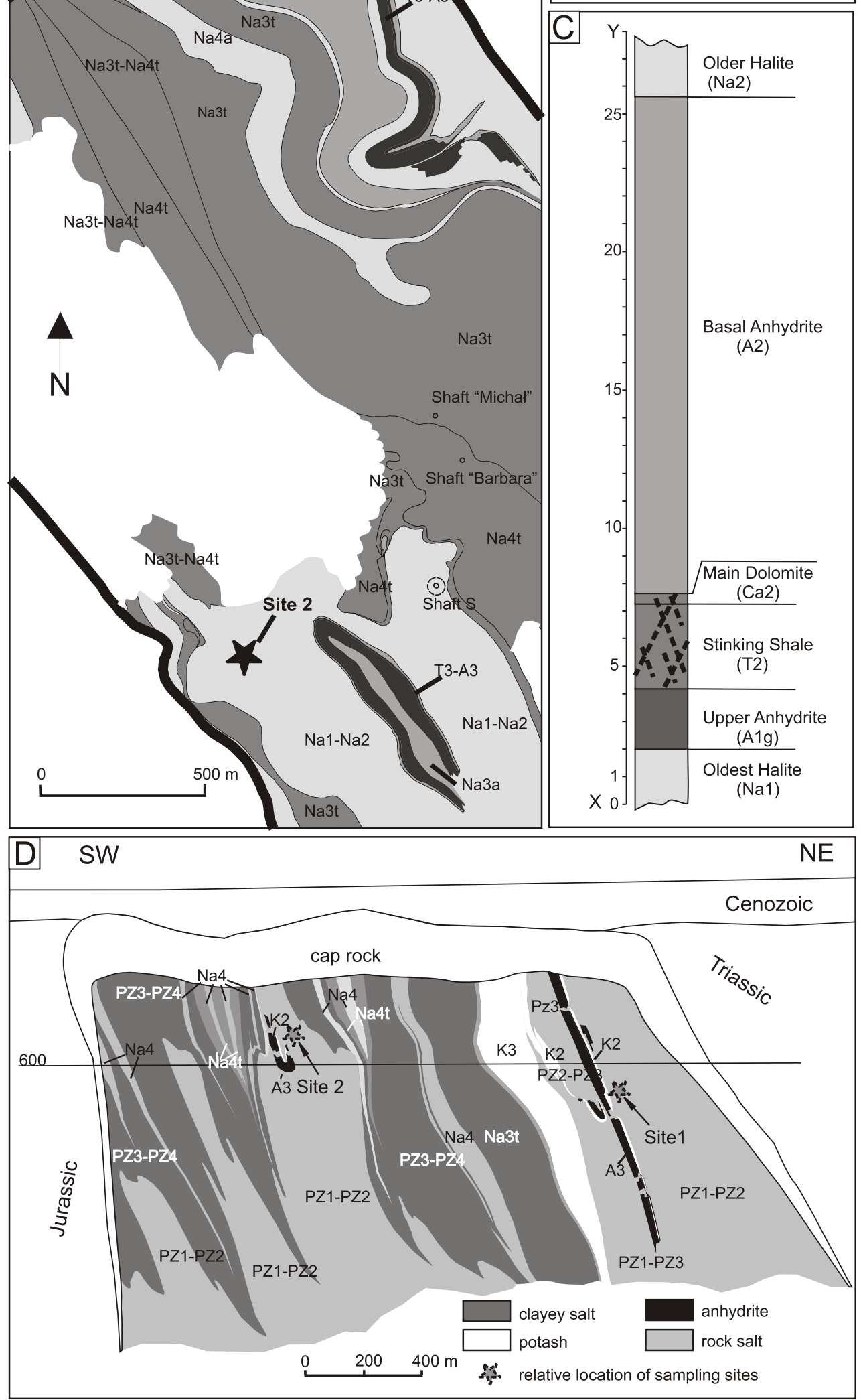
ing Shale and Main Dolomite beds show boudinage in a smaller scale and these subordinate boudins are displaced along local faults. The A1g and A2 anhydrites are more ductile than shales and dolostones, thus, they conformed to the boudins geometry, which resulted in folding of anhydrite layers adjacent to the shale and dolostone beds. Despite significant tectonic deformation, the A1g-T2-Ca2-A2 beds maintain their original superposition.

At present, the two boudins are more than $2 \mathrm{~km}$ apart in a map view (Fig. 2A), but the original distance between the investigated sections of the $\mathrm{A} 1 \mathrm{~g}-\mathrm{A} 2$ series is enigmatic. Taking into account that the sites are located in opposite flanks of the salt structure (note the PZ3-PZ4 complex separating the sampling sites in Fig. 2D), within a complexly folded salt series, the distance between the sampling sites could be even in a range of a few kilometres prior to halokinesis.

\section{SAMPLES AND METHODS}

In spite of large dimensions of the boudin in Site 1, only one gallery crosscuts the complete bed sequence (Fig. 2A, B), thus the veins containing the coaly matter could be sampled in one location. The A1g-T2-Ca2-A2 deposits are generally excluded from excavation because they commonly host hazardous gases (Burliga et al., 2008). The coaly matter was sampled in the mine gallery walls and roofs located at a depth of $680 \mathrm{~m}$ below the surface in Site 1 and from the wall and roof of the outburst cavern exposed at a depth of $572 \mathrm{~m}$ below the surface in Site 2 (Fig. 2). In both sites, there are a few generations of extensional veins, varying in mineral composition. The coalbearing veins are unique: apart from the coaly matter, they are built of calcite and fluorite as the main mineral phases, with anhydrite and halite as the subordinate ones (Madej et al., 2011). They are cut by other generations of veins, composed of halite and anhydrite. None of these younger veins contains coaly matter or calcite-fluorite paragensis.

The veins enriched in coal occur exclusively in the T2 and Ca2 strata and they appear to extinguish at the contacts with the Upper and Basal Anhydrite beds. The thickness of the T2Ca-2 strata is $\sim 3 \mathrm{~m}$ in both sites. The longest veins crosscut the whole shale-dolostone series and their maximum thickness is $\sim 5 \mathrm{~cm}$. Most of the veins are, however, traceable over a distance of a few centimetres to $1 \mathrm{~m}$ and their thickness ranges from $\sim 1$ to $\sim 5 \mathrm{~mm}$. The weakly deformed beds in Site 1 contain only few veins that are planar or lens-shaped in a cross-section (Fig. 3). In Site 2, the dolostone bed is locally brecciated and healed with calcite-fluorite veins, therefore, apart from individual planar and lens-shaped veins, a complex vein network locally occurs.

Due to dispersal of the coaly matter in veins, the carbon-rich material was extracted from several veins at each site and such bulk samples were labelled as sample 1 in Site 1 and sample 2 in Site 2. Although this study is focused on analysis of the coaly matter from veins, a sample of weakly cemented shale (Stinking Shale) was also collected at Site 2, in order to compare the dispersed organic matter (DOM) in the host rock with the vein material. Therefore, the sample 2 is distinguished into $2 a$ for the vein material and $2 b$ for the host rock matrix. The material was extracted from the rocks with use of a hammer and chisel, wrapped in aluminium foil and isolated in plastic bags.

In the laboratory, the coaly matter specimens were embedded in epoxy resin and the mounts were polished with $1 \mu \mathrm{m}$ diamond powder at room temperature. Petrographic composition of the coaly matter and random (mean) reflectance were measured according to the standard procedures (ISO 7404-2, 7404-3, 7404-5 and recommendations based on the standardization by the ICCP), with use of a photometer-equipped microscope. Non-drying immersion oil with a refraction index $\mathrm{n}=$ 1.518 (at 21 to $23^{\circ} \mathrm{C}$ and $546 \mathrm{~nm}$ wavelength light) was used for the microscopic analyses. The standard magnification was optimal for measuring reflectance in the samples (x450). To measure the amount of reflected light, the microscope photometer was calibrated according to the standard procedures presented by Stach et al. (1982). Each calibration performed in this study employed one of these standards: yttrium-garnet $(R=0.904 \%)$ and gadolinium-gallium-garnet $(1.719 \%)$.

Pyrolysis analyses of specimens were carried out on a Rock-Eval Model II instrument equipped with an organic carbon (TOC) module. The samples were heated at $25^{\circ} \mathrm{C}$ minute ${ }^{-1}$ in $\mathrm{N}_{2}$ and $\mathrm{O}_{2}$ up to $650^{\circ} \mathrm{C}$. Stable carbon isotope analyses were
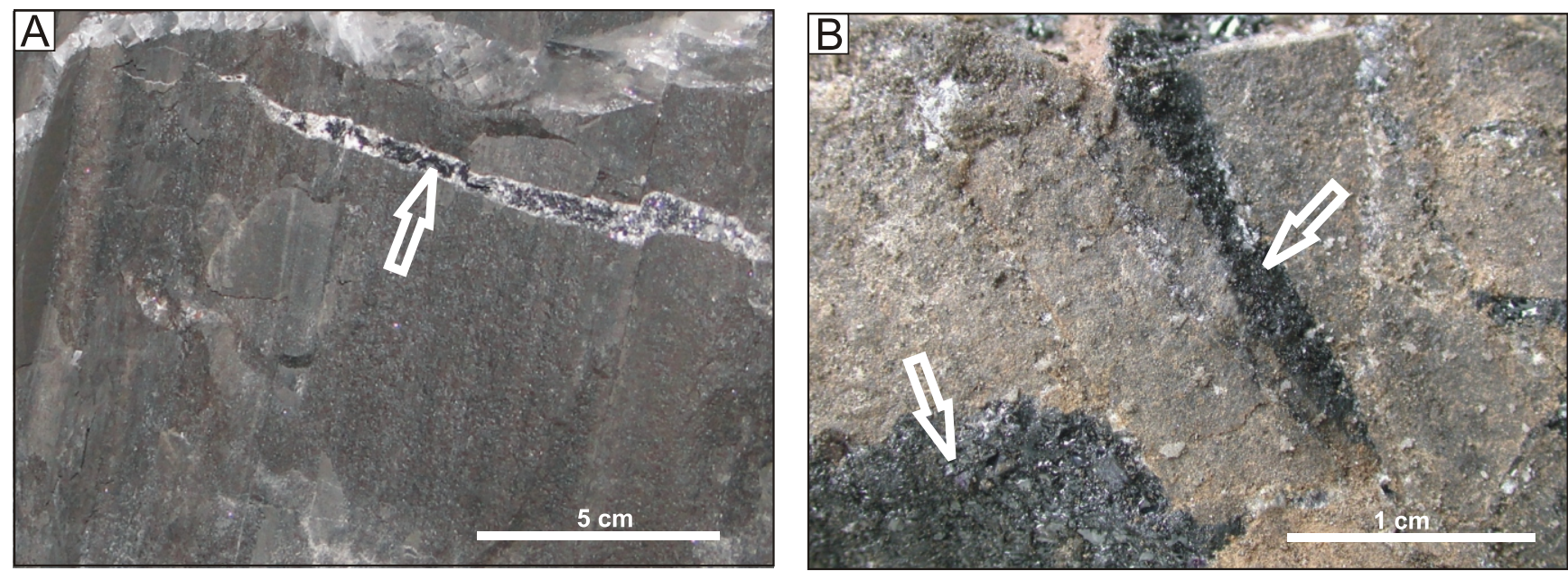

Fig. 3. Analytical material

A - Site 1: extensional veins in Stinking Shale deposits containing coaly matter (dark vein infill) and fluorite-calcite paragenesis (noticeable mainly as a whitish rim at the contact with the wall-rocks); the coal is entrapped in pores between calcite and fluorite crystals and fills the centre of the vein; a younger vein extending at the top of the image is built of halite and contains no coal and fluorite; B - Site 2: coaly matter in veins in Main Dolomite dolostone; fluorite and calcite also occur at the contact with the wall-rock 
determined on-line, using a Finnigan Delta mass spectrometer coupled with a Carlo Erba 1108 elemental analyser. The composition of stable carbon isotope is presented as the $\delta^{13} \mathrm{C}$-notation relative to PDB, with analytical precision of $\sim 0.2 \%$.

\section{RESULTS}

\section{PETROGRAPHY OF COALY MATTER}

The coaly matter sampled from veins at the two sites of the KSS is identical under naked-eye inspection. It occurs as very fine grains and as isometric or elongated chips and clasts exceeding $4 \mathrm{~mm}$ in length. It is black with intense glassy lustre and black streaks (the colour of powdered coal). The coaly matter is very brittle, showing irregular or conchoidal fracture, either with no remarkable basal cleavage or with subtle concentric cleavage. Its density measured with use of the pycnometer method is $1.45 \mathrm{Mg} / \mathrm{m}^{3}$. Microscopic inspection of samples 1 and 2 a shows that the chips of coal have an isometric or elongated habit and possess sharp edges. Some of the coal assemblages are extremely elongated, occurring as thin coatings on mineral grains or as veinlets in clays (Fig. 4). They also occur inside minerals, in particular in halite, following cleavage planes. Both veinlets and intra-crystalline coal assemblages are fractured and locally extended into en echelon trails (Fig. 4).

Coal in the veins is composed of a mixture of collotelinite and a maceral resembling micrinite, which appear as a microgranular mosaic (micrinite is $<1 \mu \mathrm{m}$ ) with irregular contours (Fig. 4). In some grains, micro-scale elongated areas of varying concentration of micrinite - ranging from dispersed grains to concentrated or pure micrinite ones - are also observed on the surface. Micrinite is very bright in reflected light (random reflectance $\sim 1.60 \%$ ), isotropic and shows higher relief than collotelinite, which indicates a higher microhardness. Both macerals do not display fluorescence in blue reflected light. The DOM from shales (sample $2 b$ ) is distinctly different to vein material. It is fine-grained $(<0.1 \mathrm{~mm})$ and, in optical analysis, it mostly displays the features of semifusinite and fusinite with minor vitrinite. The vitrinite seems to be darker than collotelinite in the chips and clasts from veins in sample $2 a$.

\section{RANDOM REFLECTANCE OF THE COAL MATTER}

Structural heterogeneity of the collotelinite surface demonstrated by the occurrence of fine micrinite assemblages results in uncertainty of random reflectance measurements, which is due to high contrast in brightness between these macerals. Because the smallest area of measurement with the reflectometer is $\sim 7.1 \mu \mathrm{m}^{2}$, the obtained mean reflectance values in each measurement area represent an average for the variable content of collotelinite and micrinite an individual location. The measured values of random reflectance have a relatively wide range for each measurement series, i.e. between 1.2 and $1.6 \%$ for samples 1 and 2a (Fig. 5).

The mean random reflectance values for coaly matter from veins are $1.40 \%$ (sample 1) and $1.38 \%$ (sample $2 a$ ), fulfilling the ICCP Standard of standard deviation below $0.06 \%$ (Table 1). A reflectogram record with use of $1 / 2 \mathrm{v}$-stadium shows two modal values, which are very distinct in sample $2 a$, with the maxima at 1.31 and $1.41 \%$ (Fig. 5A), and less distinct in sample 1 with modals at 1.33 and $1.43 \%$ (Fig. 5B). The random reflectance value of vitrinite in sample $2 b(D O M)$ is $0.82 \%$ and its reflectogram is unimodal with right-skewness (Fig. 5C). We think that it results from the occurrence of discrete areas with a stable concentration of micrinite, which can be related to initial variability in the chemical structure of source material (difference in bitumen type).

\section{ROCK-EVAL PYROLYSIS, ISOTOPE AND CHEMICAL ANALYSES}

Rock-eval analyses were carried out on coal chunks from veins. The results are listed in Table 2 . The samples show similar characteristics: high $T_{\max }$ values, increased TOC content, increased values of hydrocarbons ( $\mathrm{S} 1$ and $\mathrm{S} 2$ parameter) and the dominance of hydrocarbons over oxygen-containing compounds (S2/S3 parameters are 5.7 and 6.1 for samples 1 and $2 \mathrm{a}$, respectively). The hydrogen $(\mathrm{HI})$ and oxygen $(\mathrm{OI})$ index values are also comparable between the samples. Stable carbon isotope analysis was carried out on sample 1 and indicates the $\delta^{13} \mathrm{C}$ content of $26.3 \%$ in coaly matter (Table 2 ). Analysis of element composition of sample 1 shows that the coal is composed of $\mathrm{C}^{\text {daf }}=86.9$ wt. $\%, \mathrm{H}^{\text {daf }}=4.6 \mathrm{wt} . \%, \mathrm{~N}^{\text {daf }}=2.1 \mathrm{wt} . \%$ and $\mathrm{S}^{\mathrm{d}}=4.53$ wt.\% (Czechowski et al., 2011).

\section{DISCUSSION}

The most characteristic petrographic feature of the coal from veins in the KSS is the occurrence of a mosaic mixture of collotelinite and maceral-resembling micrinite. Similar micrinite was evidenced in various coal deposits. Teichmüller (1974) found it in meta-lignite from the Moscow coal deposits, whereas Stach et al. (1982) - in low-rank bituminous coal. It was also obtained under laboratory conditions in response to heating of coal. Nandi and Montgomery (1967) generated micrinite during soaking of coal and they pointed to high thermolability of micrinite. Koch (1970) described similar micrinite aggregates on the surface of resinite and alginite in ortho-lignite after heating coal in an autoclave at $350^{\circ} \mathrm{C}$. Those works show that although the collotelinite-micrinite mosaic is not diagnostic for a specific type of source material, it seems to be indicative of a specific stage of coalification of organic matter. The above authors associate the generation of micrinite during thermal transformation of macerals of the liptinic group (resinite, bituminite, alginite as well as sporinite) with the second coalification jump in the sapropelic coaly series. This process is well-evidenced in natural coal, in which its role increases at the final stage of catagenesis, when macerals of the liptinite group transform into vitrinite, i.e. they only depict the features of macerals of the vitrinite group. The lack of fluorescence effects in the coal from veins in the KSS confirms that the analysed organic matter has passed the second coalification jump. Identical micrinite mosaic in collotelinite at expense of disappearing macerlas of the liptinite group was also obtained by Wagner (2012, unpublished) in response to heating of ortho- and meta-lignite, and low-rank bituminous coal in the presence of water at 360 and $380^{\circ} \mathrm{C}$ during 72 hours. In addition, this process led to a variable fission yield of fluid and gaseous hydrocarbons. The latter experiment shows that such a collotelinite-micrinite mixture can originate at a very short period of time, provided that favourable thermal conditions occur.

The petrography and reflectance values of coaly matter from veins in the KSS point to a high rank of the coal. However, it is not possible to estimate the temperature of coalification based on these reflectance values because the random refle- 

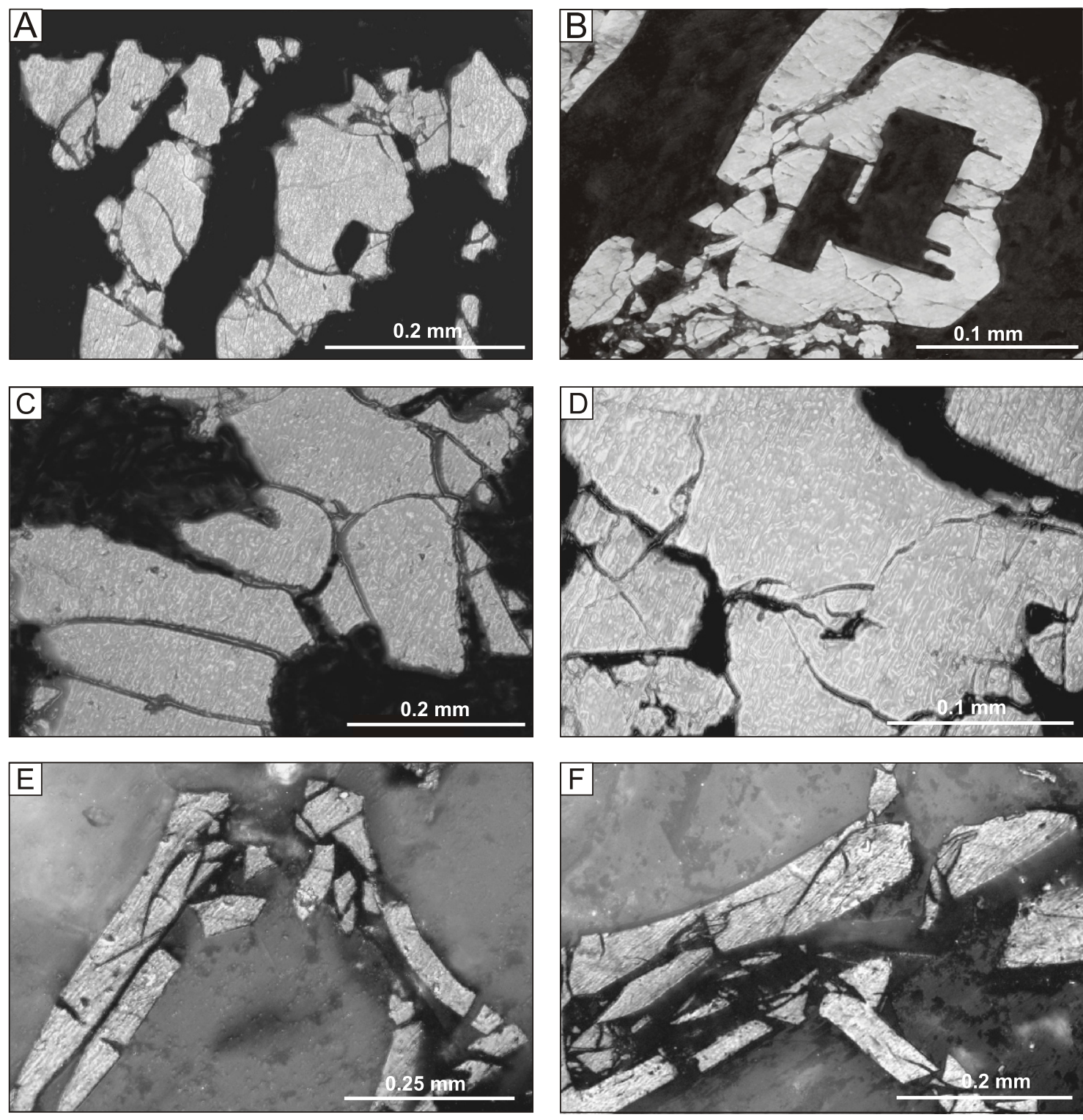

Fig. 4. Microphotographs of coalified bitumens

A, C, D - mosaic patterns of collotelinite (grey) and micrinite (whitish dots and worm-like patterns in greyish domains) in veinlets and intergranular assemblages (Sample 1); $\mathbf{B}$ - destruction of coal assemblage by epigenetic growth of euhedral mineral crystals (Sample 1); E, F - fractured veinlets of coaly matter in shale from Site 2 (reflected light, parallel polarizers); bitumens are greyish, mineral phases are black

ctance was determined on mosaic surfaces of collotelinite and micrinite, which are not suitable for the assessment of the true rank of the coal. The variable content of micrinite is extremely unfavourable in such an assessment due to its lack in low-rank and high-rank coal, as well as due to its variability in chemical properties, being dependent on micrinite genesis/origin.

The reflectogram records with two modals (Fig. 5A, B) indicate that there was initial variability in the chemical structure of source material (difference in bitumen type), which resulted in the occurrence of discrete areas with a stable concentration of micrinite. Comparing the modals - both mean and local reflectance - a very insignificant shift by $0.02 \%$ is noticeable between samples 1 and $2 a$. The distribution is left-skewed (Table
1 ), implying unusually rapid changes in coalification in relation to carbogenesis observed in most coal deposits.

The high rank of the coal is confirmed independently by the results of chemical and Rock-Eval analyses. The ratios between the main elements of coal, i.e. $\mathrm{H} / \mathrm{C}$ and $\mathrm{O} / \mathrm{C}$, determined by chemical analysis (Fig. 6), locate the sample in the field of catagenetic transformation (Krevelen, 1950). The random reflectance of the organic matter calculated on the basis of $\mathrm{C}, \mathrm{H}$ and 0 contents in the coal indicates reflectance of $R_{r}^{\circ}=$ $1.38-1.40 \%$. Such a reflectance value points to destruction of hydrocarbons generated from the source rock. In coal petrology, this is linked with a vitrinization/graphitization process termed as the second coalification jump. 

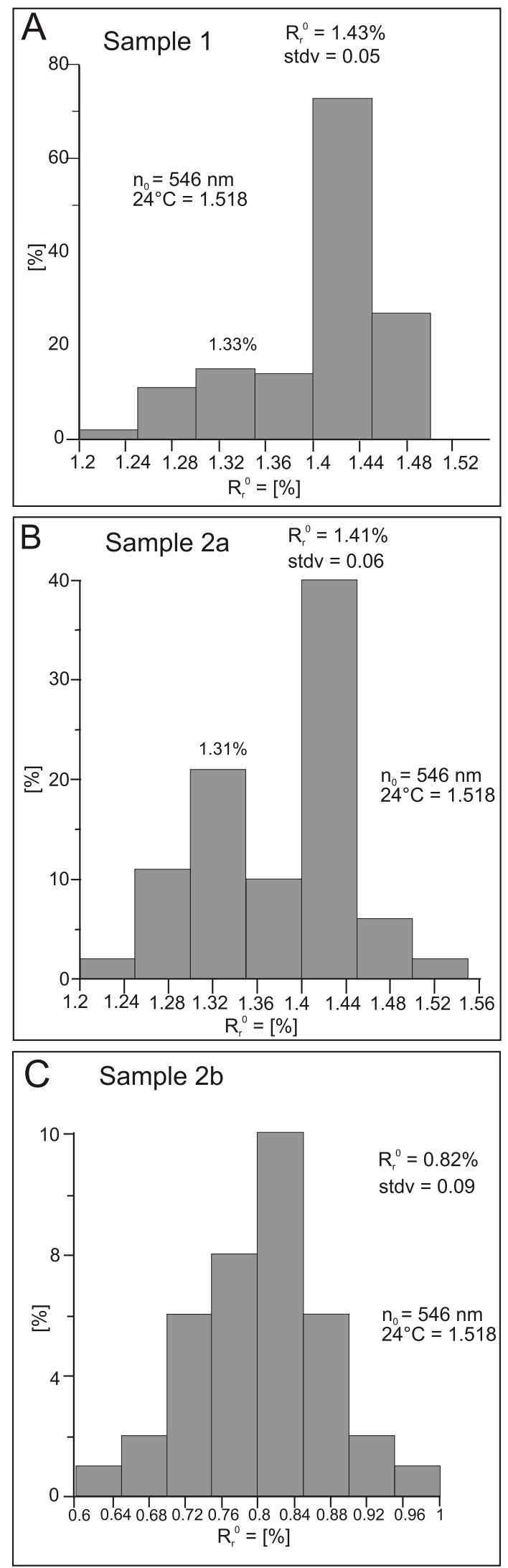

Fig. 5. Reflectograms of coaly matter from the KSS

A - Sample 1; B - Sample 2a; C - dispersed organic matter from Sample $2 \mathrm{~b} ; R_{r}^{\circ}$ - random reflectance; $R_{r}^{\circ}-$ random reflectance; stdv - standard deviation
Table 1

Averaged reflectance parameters of coaly matter from veins and wall-rocks

\begin{tabular}{|l|c|c|c|c|}
\hline $\begin{array}{c}\text { Sample } \\
\text { code }\end{array}$ & $\begin{array}{c}\text { Random } \\
\text { reflectance } \\
{[\%]}\end{array}$ & $\begin{array}{c}\text { Standard } \\
\text { deviation }\end{array}$ & $\begin{array}{c}\text { Amount of } \\
\text { measurement }\end{array}$ & Skewness \\
\hline 1 & 1.40 & 0.05 & 142 & -0.9614 \\
\hline $2 \mathrm{a}$ & 1.38 & 0.06 & 91 & -0.1836 \\
\hline $2 \mathrm{~b}$ & 0.82 & 0.10 & 35 & 0.5979 \\
\hline
\end{tabular}

In the Rock-Eval analyses, the high rank of the coal from veins is primarily indicated by high $T_{\max }$ values and increased TOC content (Table 2). The content of TOC is, however, distinctly lower than $\mathrm{C}^{\text {daf }}$ content shown by the element composition analysis and this is an additional indication on the high rank of the investigated coal. The relatively high content of TOC correlates with increased values of hydrocarbons (S1 and S2), despite coalification of the material.

The rank of the coal from veins indicated by $T_{\max }$ values suggests late-phase thermal destruction of liquid hydrocarbons and the beginning of thermogenic processes corresponding to the wet-gas phase (Peters, 1986). Although it is difficult to assess unequivocally the kerogen type based on geochemical indices, i.e. the Hydrogen Index $(\mathrm{HI})$ and Oxygen Index (OI) (Fig. 7), it seems that type II is the most likely kerogen type. However, since the points are located near the origin of the diagram (Fig. 7), the genetic type of the kerogen cannot be convincingly identified (Dembicki, 2009).

Coexistence of different macerals in the host rocks and veins (macerals in the type of semifusinite and fusinite with minor vitrinite vs. collotelinite and micrinite) and contrasting difference in random reflectance between the DOM in shales and the coal in veins $(0.82 \%$ vs. $1.38-1.40 \%)$ indicate that organic matter in wall-rocks and veins has undergone heterogeneous heating. We assume that the random reflectance value of $0.82 \%$ for the DOM from shales demonstrates the maximum burial maturity of $\mathrm{OM}$ in the Stinking Shale. In terms of hydrocarbon generation, it points to an early phase of liquid hydrocarbon generation. Because the high-rank coal occurs in veins which developed due to a tectonic event (fracturing of shales and dolostones), the circulation of hot fluids along a fissure system seems the most plausible mechanism for the observed thermal heterogeneity. Hydrothermal fluids related to igneous intrusions or fault zones are known to introduce anomalies in maturity of organic matter in various geological settings (e.g., Simoneit et al., 1986; Galushkin, 1997; Losh et al., 1999; Lampe and Person, 2000; Othmana et al., 2001). The above authors showed that organic matter in veins displays much higher maturity than wall-rocks, and that the maturity decreases with the distance from the heat source. In the KSS case, coalification of bitumens is observed only in veins, implying that hot fluids had a limited ability to penetrate the weakly permeable matrix of the host rock, but could migrate along fractures. Such a distribution of high-rank coal allows for drawing two major conclusions about the nature and conditions of the hydrothermal event. Firstly, hydrothermal fluid migration was a relatively short-lived event because it could not heat the whole bed, despite drastic alteration of bitumens along the conduits. Secondly, the clays/shales must have been dry or lithified prior to the hydrothermal event, in order to enable the development of extensional fractures in shales and dolostones which were used by migrating fluids and filled with coaly matter and epigenetic minerals. The calcite-fluorite paraganesis occurring in the veins with high-rank coal supports the concept of hydrothermal influx to the Stinking Shale and Main Dolomite beds, because a prolific source of fluo- 
spectively). Although the actual timing of the hydrothermal event cannot be The results of Rock-Eval and $\delta^{13} \mathrm{C}$ isotopic analyses of coaly matter from veins

\begin{tabular}{|l|c|c|c|c|c|c|c|c|}
\hline $\begin{array}{c}\text { Sample } \\
\text { code }\end{array}$ & $\begin{array}{c}\mathrm{TOC} \\
{[\%]}\end{array}$ & $\begin{array}{c}\mathrm{T}_{\max } \\
{\left[{ }^{\circ} \mathrm{C}\right]}\end{array}$ & $\begin{array}{c}\mathrm{S} 1 \\
{[\mathrm{mg} / \mathrm{g}]}\end{array}$ & $\begin{array}{c}\mathrm{S} 2 \\
{[\mathrm{mg} / \mathrm{g}]}\end{array}$ & $\begin{array}{c}\mathrm{S} 3 \\
{[\mathrm{mg} / \mathrm{g}]}\end{array}$ & $\begin{array}{c}\mathrm{HI} \\
{[\mathrm{mg} / \mathrm{g} \mathrm{TOC}]}\end{array}$ & $\begin{array}{c}\mathrm{Ol} \\
{\left[\mathrm{mg} \mathrm{CO}_{2} / \mathrm{g} \mathrm{TOC}\right]}\end{array}$ & $\begin{array}{c}\delta^{13} \mathrm{C} \\
{[\%]}\end{array}$ \\
\hline 1 & 14.6 & 474 & 6.4 & 17.7 & 3.1 & 121 & 20 & -26.3 \\
\hline $2 \mathrm{a}$ & 15.2 & 470 & 6.8 & 20.8 & 3.4 & 138 & 23 & - \\
\hline
\end{tabular}
assessed, the above structural constraints limit its occurrence to the Late Zechstein-Early Triassic time span. Rim synclines on seismic sections across the KSS area (Krzywiec, 2004, 2012) show that the upward flow of salt to a diapiric structure started in the Middle Triassic, thus the A1g-A2 bed

rine is required for fluorite crystallisation. This mineral has been found so far exclusively in veins in the T2-Ca deposits in the KSS. It is rather unlikely that the high concentration of fluorine is related to residual brines and to an episodic, unusual change in the chemistry of sea water in the Zechstein Basin during the deposition of this shale-dolostone series. Taking into account that coalification of bitumens is observed in boudins separated by a distance of a few kilometres, it suggests that the hydrothermal event took place before the $\mathrm{T} 2-\mathrm{Ca} 2$ beds lost their continuity, i.e. prior to the isolation of the boudins by salt in interboudin necks. Rock salt is very weakly permeable, therefore the circulation of fluids between isolated boudins is extremely unlikely. On the other hand, the vein system evidences bed extension, therefore, the hydrothermal event must have occurred after initiation of deformation of the Zechstein salt series and can be linked with the initial stage of boudinage of the most competent beds amongst the Zechstein series, i.e. of shale and carbonate beds. The anhydrite beds, underlying and overlying the T2-Ca2 beds, are less competent than shales and carbonates and, moreover, the whole sulphate-shale-carbonate-sulphate bed complex was underlain and overlain by ductile rock salt beds ( $\mathrm{Na} 1$ and $\mathrm{Na} 2$, re-

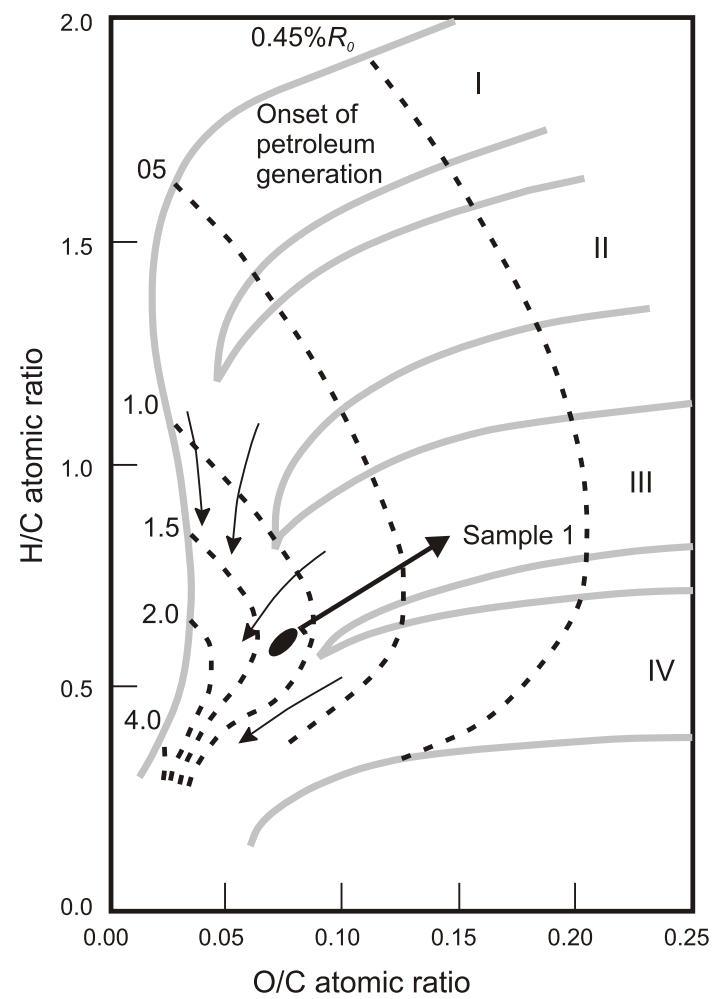

Fig. 6. Atomic hydrogen/carbon ratio vs. oxygen/carbon ratio for kerogen in coaly matter from Site 1 (according to Krevelen, 1950)

The sample locates in the field of late catagenesis; I-IV - genetic type of kerogen, $\mathrm{R}_{0}$ - random reflectance must have become discontinuous by that time.

The hydrothermal event is most probably related to the activity of the fault located in the basement under the KSS, triggered by regional extension, which prevailed in the Polish Zechstein and Mesozoic basins from the Zechstein until the Late Cretaceous (Dadlez et al., 1995; Dadlez, 2003; Krzywiec, $2004,2012)$. The distribution of sedimentary facies in the Zechstein Basin (Wagner, 1994) indicates that basement faults were active during deposition of the Zechstein evaporitic series. The contrasting difference in the thickness of Middle and Upper Triassic deposits on the NE and SW flanks of the KSS ( 1 km difference; see seismic sections in Krzywiec, 2004, 2012) implies that a normal basement fault under the salt structure was particularly active in the Triassic. The extension of the basement could open conduits for hot fluids to enable their injection under extremely high fluid pressures into the only permeable bed within the Zechstein salt series. A scheme of the events is presented in Figure 8. We can only speculate on the pathways for hot fluids in the Na1 rock salt bed, because no convincing evidence on their existence has been found so far. Such pathways could, however, be obliterated due to flow of rock salt and

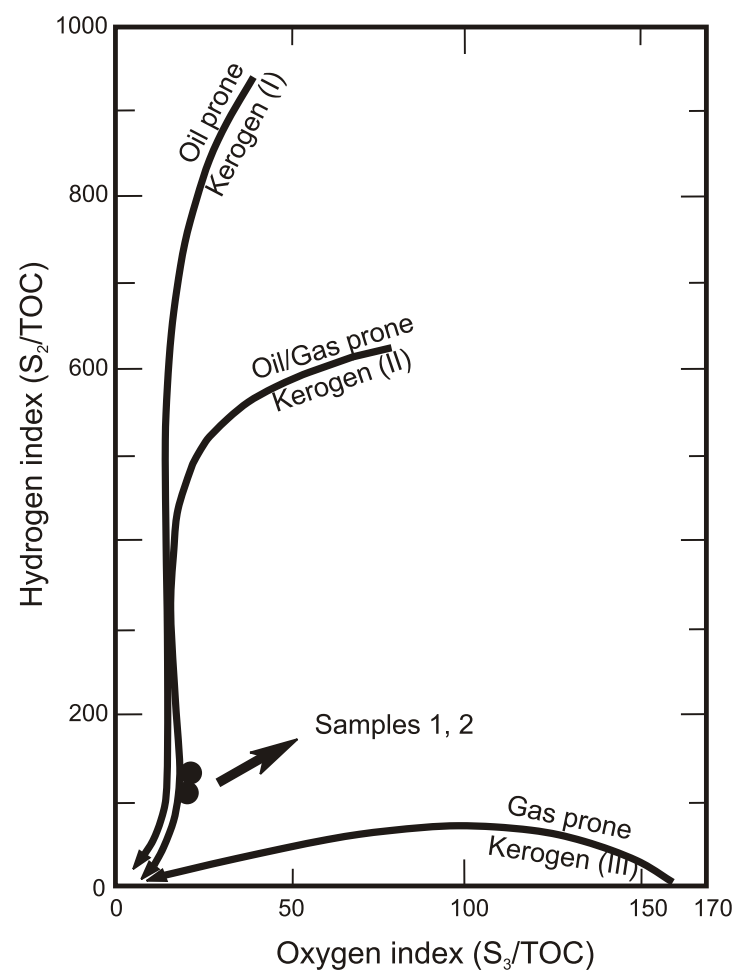

Fig. 7. Rock-Eval hydrogen index vs. oxygen index for coaly matter from Site 1 (diagram based on Espitalié, 1986)

$\mathrm{S}_{2}$ - residual genetic hydrocarbon potential (mg/g of rock); $\mathrm{S}_{3}-\mathrm{CO}_{2}$ content ( $\mathrm{mg} \mathrm{CO} / \mathrm{g}$ of rock); TOC - total organic carbon, I-III - kerogen type 


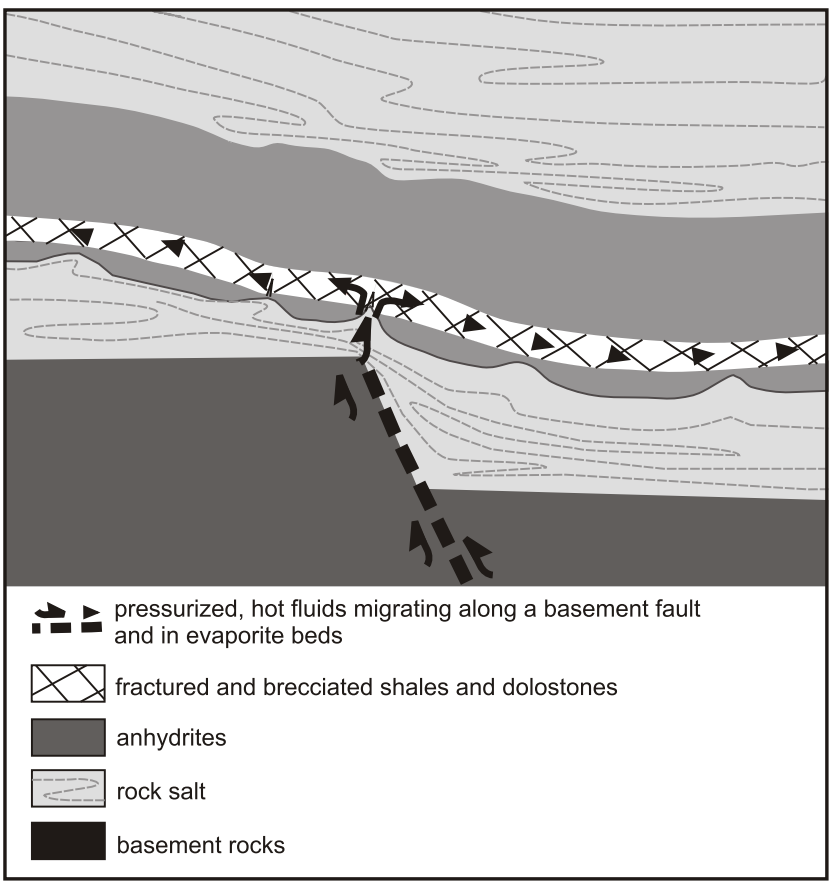

Fig. 8. Schematic model of hot fluid injection into shales and dolostones overlying the Oldest Halite rock salt bed

The extension of the basin and growth of a normal basement fault initiated rock salt flow and boudinage of more competent anhydrite, shale and dolostones beds. Relative variation in competence between the latter rocks led to brittle fracturing of the most competent shale-dolostone beds, whereas the underlying less competent thin anhydrite bed was pinched out or budinaged locally. Because the most ductile oldest rock salt bed became thinned above the basement fault ramp during the fault growth, pressurized hot fluids migrating along the basement fault zone could locally dissolve rock salt and penetrate fractured shales and dolostones. The thick anhydrite bed above these fractured rocks was not boudinaged at the time of coalification of hydrocarbons; it constituted an effective seal. The whole complex of competent beds was progressively folded and boudinaged at later stages of the KSS development, after the entrapment of coal in veins

dynamic recrystallisation of halite. Analogue models of salt flow above the basement fault show that rock salt beds can be extremely thinned out above the basement fault ramp (see Burliga et al., 2012), which could facilitate penetration of hot fluids into fractured shales and dolostones. Overpressured hot fluids migrating from the deep basement could lead to localised dissolution of salt, fracturing and resealing of the salt bed. The repetitive dilation and sealing of rock salt beds in response to migration of hot fluids was evidenced by Schoenherr et al. (2007a, b) in a similar rock salt-carbonate stringer setting, and thus similar processes could also operate in the KSS region. Alternatively, if the hydrothermal event took place at a relatively shallow burial depth of the Zechstein series, the rock salt could deform as a brittle or semi-brittle rock and a system of fractures could also develop in the rock salt bed, being sealed at later stages of rock salt deformation.

We cannot determine unequivocally the origin of the bitumens. Because the high-rank coal has been observed so far exclusively in the T2-Ca2 beds, it can be assumed that hot fluids did not carry bitumens from deeper sedimentary formations (e.g., Carboniferous), but contributed to their generation and coalification within the organic matter-rich Z2 shale and carbonate beds. On the other hand, we cannot exclude that some bitumens were carried with fluids from deeper levels. The lack of high-rank coal in the matrix of the host rocks indicates fast migration of hot fluids along the network of fractures and their relatively rapid cooling, as well as temperature equilibrium within the shale and carbonate beds. The temperature of hot fluids is enigmatic, however, the high rank of coal indicates that the temperatures were probably over $200^{\circ} \mathrm{C}$. The in situ generated bitumens and coal were probably distributed along fractures and then deposited in fissures after flow velocity dropped or their inflow ceased.

\section{CONCLUSIONS}

The investigated coaly matter from the KSS shows petrographic and geochemical characteristics of mixed vitrinite-inertinite (meta-humic) high-rank coal. Based on the measurements of random reflectance values $\left(R_{r}^{\circ}\right.$ in the range of $1.38-1.40 \%$ and locally even $1.60 \%$ ) and element composition, the coaly matter is comparable to meta- and para-bituminous coal.

The coaly matter most probably originated from liquid bitumens which were extracted and generated in a local source rock from dispersed organic matter. The Stinking Shale rocks which have high TOC values and host veins and veinlets with coal are the best candidate for their source. The liquid hydrocarbons must have been incorporated by the hydrothermal fluids entering the shale and carbonates via a fracture network - the conduits for hottest fluids - where the bitumen coalified and obtained the characteristics typical of late catagenetic alteration of organic matter. This alteration can be assessed as advanced vitrinization and the beginning of graphitization of bitumens, which is a poorly recognized process defined as the second coalification jump. These processes must have been episodic and ephemeral because the analysed material does not show features of thermal alteration of bitumens as a result of normal burial alteration. This is implied, among others, by much higher reflectance of coaly matter from the KSS than that of anthraxolites or kerites (e.g., Szafran and Wagner, 1999). Physico-chemical properties of the analysed matter are similar to those of high-rank coal of metahumic type.

The coalification of bitumens is limited to an early stage of tectonic deformation of the Zechstein salt series (Late Permian or Early Triassic). It most probably occurred during (sub)horizontal flow of rock salt, which was induced by regional extension and normal displacement on the basement fault. The extension led to fracturing and boudinage of the most competent shale-carbonate beds of the second Zechstein cycle, which opened conduits for hot and pressurized fluids migrating along the basement fault area.

Acknowledgments. We thank the "Kłodawa" Salt Mine authorities for permission to carry out the investigations and to the mine geologists who helped in the underground studies. We also acknowledge F. Czechowski, who significantly contributed to this paper by stimulating discussions, and the reviewers: J. Schoenherr and an anonymous one, who helped to improve the manuscript. This study was partly financed from the funds granted by the Polish Ministry for Science and Higher Education, and partly from the grants of the Academy of Mining and Metallurgy and the Institute of Geological Sciences of the University of Wrocław. 


\section{REFERENCES}

Burliga, S., 1996a. Implications for early basin dynamics of the Mid-Polish Trough from deformational structures within salt deposits in central Poland. Geological Quarterly, 40 (2): 185-202.

Burliga, S., 1996b. Kinematics within the Kłodawa salt diapir, central Poland. Geological Society Special Publications, 100: 11-21.

Burliga, S., Janiów, S., Sadowski, A., 2005. Mining perspectives in the Kłodawa Salt Mine considering modern knowledge on tectonics of the Kłodawa Salt Structure (in Polish with English summary). Technika Poszukiwań Geologicznych Geosynoptyka Geotermia, 4: 17-25.

Burliga, S., Czechowski, F., Hojniak, M., 2008. Gas hazards in the Kłodawa Salt Structure as a Zechstein stratigraphic indicator (in Polish with English summary). Mineral Resources Management, 24: 69-81.

Burliga, S., Koyi, H.A., Chemia, Z., 2012. Analogue and numerical modelling of salt supply to a diapiric structure rising above an active basement fault. Geological Society Special Publications, 363: 395-408.

Czechowski, F., Burliga, S., Hojniak, M., 2011. Geochemistry of hydrocarbons from the first documented occurrence of Main Dolomite (Ca2) in the Kłodawa Salt Dome (in Polish with English summary). Geologia, 37: 231-244.

Dadlez, R., 2003. Mesozoic thickness pattern in the Mid-Polish Trough. Geological Quarterly, 47 (3): 223-240.

Dadlez, R., Narkiewicz, M., Stephenson, R.A., Visser, M.T.M., Wees, J-D., van, 1995. Tectonic evolution of the Mid-Polish Trough: modelling implications and significance for central European geology. Tectonophysics, 252: 179-195.

Dembicki, H. Jr., 2009. Three common source rock evaluation errors made by geologists during prospect or play appraisals. AAPG Bulletin, 93: 341-356.

Espitalié, J., 1986. Use of Tmax as a maturation index for different types of organic matter: comparison with vitrinite reflectance. In: Thermal Modeling in Sedimentary Basins (ed. J. Burrus): 475-496. Editions Technip, Paris.

Galushkin, Y.I., 1997. Thermal effects of igneous intrusions on maturity of organic matter: a possible mechanism of intrusion. Organic Geochemistry, 26: 645-658.

Hoffmann, P., Leythaeuser, D., 1995. Migration of hydrocarbons in carbonate source rocks of the Stassfurt member (Ca2) of the Permian Zechstein, borehole Aue 1, Germany: the role of solution seams. Organic Geochemistry, 23: 597-606.

Karnkowski, P.H., 2007. Permian Basin as a main exploration target in Poland. Przeglad Geologiczny, 55: 1003-1015.

Koch, J., 1970. Braunkohlenharze, Verwitterung und Verkohlung von Harzen. Erdöl und Kohle, 23: 633-638.

Kotarba, M., Wagner, R., 2007. Generation potential of the Zechstein Main Dolomite (Ca2) carbonates in the Gorzów Wielkopolski-Międzychód-Lubiatów area, geological and geochemical approach to microbial-algal source rock. Przeglad Geologiczny, 55: 1025-1036.

Kotarba, M.J., Więcław, W., Stecko, Z., 2000. Composition, origin and habitat of natural gases in the Zechstein Main Dolomite strata of the western part of the Fore-Sudetic area (SW Poland) (in Polish with English summary). Przegląd Geologiczny, 48: 429-435.

Kotarba, M.J., Peryt, T.M., Kosakowski, P., Więcław, D., 2006. Organic geochemistry, depositional history and hydrocarbon generation modelling of the Upper Permian Kupferschiefer and Zechstein Limestone strata in south-west Poland. Marine and Petroleum Geology, 23: 371-386.

Krevelen, D.W., van, 1950. Graphical-statistical method for the study of structure and reaction processes of coal. Fuel, 29: 269-84.

Krzywiec, P., 2004. Triassic evolution of the Kłodawa Salt Structure: basement-controlled salt tectonics within the Mid-Polish Trough (Central Poland). Geological Quarterly, 48 (2): 123-134.

Krzywiec, P., 2012. Mesozoic and Cenozoic evolution of salt structures within the Polish basin: an overview. Geological Society Special Publications, 363: 381-394.
Lampe, C., Person, M., 2000. Episodic hydrothermal fluid flow in the Upper Rhinegraben (Germany). Journal of Geochemical Exploration, 69-70: 37-40.

Leythaeuser, D., Borromeo, O., Mosca, F., Di Primio, R., Radke, M., Schaefer, R.G., 1995. Pressure solution in carbonate source rocks and its control on petroleum generation and migration. Journal of Marine and Petroleum Geology, 12: 717-733.

Lockhorst, A., ed., 1998. NW European Gas Atlas. British Geological Survey, Bundesanstalt für Geowissenschaften und Rohstoffe, Danmarks og Gronlands Geologiske Undersogelse, Nederlands Instituut voor Toegepaste Geowetenschappen, Państwowy Instytut Geologiczny, European Union.

Losh, S., Eglinton, L.B., Schoell, M., Wood, J.R., 1999. Vertical and lateral fluid flow related to a large growth fault, South Eugene Island Block 330 Field, offshore Louisiana. AAPG Bulletin, 83: 244-276.

Madej, S., Burliga, S., Drzewicki, W., 2011. Calcite-fluorite paragenesis in Zechstein rocks of the Kłodawa Salt Dome - preliminary data. Mineralogia - Special Papers, 38: 133-134.

Nandi, B., Montgomery, D.S., 1967. Thermal behaviour of massive and granular micrinite. Fuel, 46: 394-398.

Othmana, R., Arourib, K.R., Warda, C.R., McKirdy, D.M., 2001. Oil generation by igneous intrusions in the northern Gunnedah Basin, Australia. Organic Geochemistry, 32: 1219-1232.

Peryt, T.M., Geluk, M.C., Mathiesen, A., Paul, J., Smith, K., 2010. Zechstein. In: Petroleum Geological Atlas of the Southern Permian Basin Area (eds. J.C. Doornenbal and A.G. Stevenson): 123-147. EAGE Publications, b.v. (Houten).

Peters, K.E., 1986. Guidelines for evaluating petroleum source rock using programmed pyrolysis. AAPG Bulletin, 70: 318-329.

Schoenherr, J., Littke, R., Urai, J.L., Kukla, P.A., Rawahi, Z., 2007a. Polyphase thermal evolution in the Infra-Cambrian Ara Group (South Oman Salt Basin) as deduced by solid bitumen maturity. Organic Geochemistry, 38: 1293-1318.

Schoenherr, J., Urai, J.L., Kukla, P.A., Littke, R., Schléder, Z., Larroque, J.M., Newall, M.J., Al-Abry, N., Al-Siyabi, H.A., Rawahi, Z., 2007b. Limits to the sealing capacity of rock salt: A case study of the Infra-Cambrian Ara Salt from the South Oman Salt Basin. AAPG Bulletin, 91: 1541-1557.

Simoneit, B.R.T., Summerhayes, C.P., Meyers, P.A., 1986. Sources and hydrothermal alteration of organic matter in Quaternary sediments: a synthesis of studies from the Central Gulf of California. Marine and Petroleum Geology, 3: 282-297.

Słowakiewicz, M., Mikołajewski, Z., 2011. Upper Permian Main Dolomite microbial carbonates as potential source rocks for hydrocarbons (W Poland). Marine and Petroleum Geology, 28: 1572-1591.

Stach, E., Mackovsky, M., Teichmüller, M., Taylor, G.H. Chandra, D., Teichmüller, R., 1982. Coal Petrology. Gebrüder Bornträger, Berlin-Stuttgart.

Szafran, S., Wagner, M., 1999. Petrologic studies of Miocene organic matter in eastern part of the Carpathian Foredeep, Southern Poland (in Polish with English summary). Zeszyty Naukowe Politechniki Śląskiej, 243: 131-138.

Teichmüller, M., 1974. Über neue Macerale der Liptinit-Gruppe und die Entstehung des Micrinits. Fortschritte in der Geologie von Rheinland und Westfalen, 24: 37-64.

Wagner, R., 1994. Stratigraphy of deposits and development of Zechstein Basin in Polish Lowlands (in Polish with English summary). Prace Państwowego Instytutu Geologicznego, 146: 5-62.

Wagner, R., 1998. Zechstein. In: Palaeogeographical Atlas of the Epicontinental Permian and Mesozoic in Poland (1:2 500 000) (eds. R. Dadlez, S. Marek and J. Pokorski). Polish Geological Institute, Warszawa.

Ziegler, P.A., 1990. Geological Atlas of Central and Western Europe. Second edition, Shell Internationale Petroleum Maatschappij B.V., Geological Society Publishing House: 74-77. 